\title{
Perception of Gallery Managements on Optimisation of Daylighting for Energy Efficiency in the Post Construction Architecture of Gallery Spaces
}

\author{
Ajayi Oluwole Oluwaseun* Akande Oluwaseun Mayowa Onigbogi Olayinka Odunola \\ Department of Architecture, Faculty of Environmental Sciences, LadokeAkintola University of Technology, \\ Ogbomoso, Nigeria
}

\begin{abstract}
Lighting in art galleries is fundamental to the building's function and has a direct impact on the visual experience, preservation of art and most importantly the energy used. Despite the recent advancements in architecture, most galleries are yet to embrace the use of day lighting for its cost effectiveness and energy efficiency. This study therefore evaluated the perception of gallery managements in selected galleries on the optimization of day lighting with a view to proposing an art gallery in Eko-Atlantic, Lagos State. The study purposively selected 15 most visited galleries of the known 21 art galleries in Lagos state. The sample size was distributed across the three prevalent gallery typologies which are purpose-built, converted and space-in-facilities galleries which are leased spaces in other facilities. Total enumeration sampling technique was used to survey the responses of the members that constitute the management team in the art galleries 100 copies of questionnaire were administered based on staff strength of existing galleries to obtain information on socio-economic characteristics of respondents, sources and cost of power Designer's observation was used to assess the characteristics of the galleries and a lux meter was used to measure illumination levels. Frequency counts and percentages were used to explain socio-economic characteristics of the respondents, cross tabulation was employed to analyze the gallery types with cost of power supply and Likert scale was used to evaluate staff perception on the use of day lighting. Power Usage Index (PUI) was developed to measure respondents' perceived most important areas for power usage in the gallery space. Supply, staff members' perception on optimisation of day lighting and use of artificial lighting. The study revealed that Majority $(68.9 \%)$ of the galleries were converted spaces. All the gallery types relied on generators and electricity supply from the national grid for lighting, hence over (N100, 000) hundred thousand was spent monthly to power the galleries. The highest value of PUI (4.73) was established for lighting being the most important reason for power in the gallery. The study showed that majority $(68.7 \%)$ of the respondents agreed the use of daylight was cost-effective and energy-efficient. However, only $14.3 \%$ of the galleries utilized the north-south orientation to maximize solar gain during the daytime. The study concluded that the strategic adoption of day lighting was considered a significant tool for energy and cost efficiency in the gallery space. The study recommended the need to adopt the north-south orientation to maximize solar gain
\end{abstract}

Keywords: Art gallery, Optimization, day lighting Energy efficiency, Visual experience

DOI: $10.7176 / \mathrm{JEES} / 11-5-07$

Publication date:May $31^{\text {st }} 2021$

\section{Introduction}

Art practice in Nigeria has drastically improved and grown in the last two decades, this is due to the number of art galleries and the level of art activities exhibitions, conferences, symposiums which have culminated into the development of visual arts in Nigeria (Joshua and John 2015). Today, art galleries are found in every major city in the world, they are now included in every tourist guide along with museums. They also serve as a melting point for the gathering of a select and sophisticated crowd thereby contributing substantially to the cultural life of a city .Young and budding artists are also supported by these galleries through organizing exhibitions that attract potential collectors (Robertson and Thompson, 2008). Furthermore Joshua and John 2015 opined that this tremendous growth is also due to new galleries springing up, and her enlarging clientele base. They observed the record sales of Nigerian artworks around the world and envisaged that in the near distant future, art will become a part of the major drivers of the economy. Evidently, the major players in the art business in Nigeria are gallery owners; among them are Art-house Contemporary Ltd, Signature gallery, Terra-Kulture, Treasure House, Nimbus gallery and others.

Consequently, there will be a surge of more art galleries in the nearest future in a bid to keep up with the rapid growth of the market. This would place more demand on power supply, especially in urban centers like Lagos which is gradually becoming a hub for artists from around the world. However, the poor state of power supply in the country has left the galleries with no choice but to rely on the epileptic power supply or the rather expensive alternative of the petrol/diesel generator which is largely the most prevalent but unsustainable alternative (Business Day 2017). Hence this study aims to assess the gallery managements' perception on the 
optimisation of daylight for energy efficiency. It also intends to demonstrate how galleries can achieve extensive energy savings by utilizing energy efficient technologies that can provide suitable exhibition display conditions for the art works.

However it is estimated that buildings contribute to one third of the total global annual greenhouse gas emission primarily by the use of fossil fuel during their operational phase and consumes up to $40 \%$ of all energy (Adeleke, 2010). Ameer (2015) explored the importance of daylight in art galleries and how it can enhance artworks, as well as its visual quality among the viewers, Liliana et al, (2004) investigated the daylight performance in museums and galleries and further indicated the different lighting problems in the exhibition areas, Fernanda and Koen (2008) further investigated the relationship between the satisfaction and behavior of visitors based on the type of lighting in museum, specifically the use of daylight. One major index for measuring a nation's economic prosperity is the per-capita energy consumption and the higher the per-capita consumption of energy of a country, the more prosperous is the nation (Arvind and Tejinder, 2009). Developed nations have much higher per capita energy consumption than the developing world, however, with the limited available energy resources; there is a need to judiciously harness it for the longest period of time. Over the years, interest in the use of daylight has particularly increased as a result of the understanding that electric lighting represents a major energy consumer. The introduction of innovative, advanced day lighting strategies and systems is therefore gradually becoming a sustainable alternative that has been found to considerably reduce a building's electricity consumption and significantly improving the quality of light in an indoor environment while also reducing operational cost. (Fördergemeinschaft Gutes Lich, 2007).

Energy efficiency thus touches on the use of the lighting. A strategy for achieving an energy-efficient lighting design is to ensure that the minimum energy is used to produce the lighting needed. This inevitably could involve using daylight where available and appropriate, with complementary electric lighting used only when necessary which should however be controlled automatically for effectiveness of the strategy. The adoption of artificial lighting has been widely embraced and is highly essential in setting the tone for the viewing and purchase of art works in galleries, however, little or no literature is available on perception of gallery managements especially in Nigeria as regards the adoption of day lighting as an energy-efficient method for illumination in spite of the recent advancements in building technology. Therefore this paper addresses the adoption of day lighting as a significant tool for energy and cost efficiency in the architecture of gallery space.

\subsection{Art Galleries}

An art gallery is a room or series of rooms where works of art are exhibited and are usually managed by curators who specializes in the different types of art (Onal, 2017). Typically, the arts works in an art gallery are for sale with the exception of, special permanent collection, or sponsored unique display of art. Some could also be dedicated to exhibiting a specific medium such as furniture, oil painting, jewelry, photography, sculpture, textiles, or pottery. This could be specific to a region or time period or a general collection of works in that medium from various artists. Other types of galleries could have a specific cultural focus which could be political, historical, or medium based. For example, a gallery might choose to only display contemporary African art, while another gallery might focus on post-modern century Jewish artists, or political artwork from African refugees. These galleries are typically open to members of the public, to encourage cultural education and enrichment (Onal, 2017). Today, art galleries are found in every major city in the world, they are now included in every tourist guide along with museums.

\subsubsection{Types of Art Galleries}

Art galleries are categorized based on a the type of artworks and building types and as such includes the following

1. Modern art gallery: A modern or contemporary art gallery is a place where contemporary art is shown for exhibition and/or for sale.

2. Sculpture art gallery: a gallery where into three-dimensional art objects are exhibited for sale

3. Photography art gallery: It's a contemporary art gallery which focuses on photo, fine art prints and videobased pieces.

4. Historical art gallery: also called public galleries. Also frequently, a series of rooms dedicated to specific historic periods

5. Textiles art gallery: an art gallery that exhibits art created by decorated objects with textiles or creation with textiles.

\subsubsection{Type of Gallery Design}

1. Purpose Built Gallery Spaces: This category includes facilities for temporary exhibitions, and galleries with permanent collections which have temporary, as well as permanent exhibitions, and related storage, curatorial and education functions. These may be collocated with other cultural facilities such as museums or art venues. 
2. Galleries in Facilities: Examples in this category includes: small multi-purpose performing arts venues suitable for small-scale performances and exhibitions, workshops, talks, film screenings. Suitable for most locally based arts activities not requiring specialist equipment or fit out, Hotels, Civic Centers, etc.

3. Converted Buildings: These are galleries in spaces originally designed for other purpose but are now converted into galleries. Examples include residential buildings, factories, worship centers, and warehouses. (Onal, 2017).

\subsection{Day lighting in a Space}

A preference for 'natural' light have been expressed by many curators and visitors in galleries and museums as windows allow visitors to get a feel for their location or orientation in the building by seeing external landmarks. However, the brightness of the views from the outdoors typically needs to be reduced by screening to avoid losing the visitors adaptation to low light. In other to achieve successful day lighting in buildings, trade-offs and optimization maybe necessary between competing design features (e.g. light distribution, glare, solar gains, views, etc.), while keeping in mind other considerations such as façade layout, space configuration, internal finishes and choice/operation of shading devices. When a day lighting strategy is thoughtfully designed, it affords tangible energy savings, so long as it reduces energy use for artificial lighting and prevents glare and other visual discomfort (such as contrast, adaptation problems and internal reflections (Sergio, 2008). These decisions for day lighting in a space must also be considered alongside thermal efficiency and cost, amidst other things. Its distribution in a space is the key determinant in the lit appearance of the space. Bright walls have been found to make the space feel bright and well-lit however dark walls, and especially dark corners which makes the space feel gloomy; regardless of how well lit the exhibits are. Sunlight must be confined to the upper parts of an exhibition space shouldn't be allowed to allowed to reach the exhibit if conservation limits are to be maintained. Areas such as sculpture courts and other spaces where lighting conservation limits are of less concern are an exception to this. However, the lighting level in one space tends to set an adaptation level of the viewer and may make the transition into a darker gallery difficult.

Use and Control of Daylight Natural light has many attractions in a museum or gallery for of its variation in pattern and intensity, also for its consistently good colour quality; however it has to be controlled for conservation reasons. Direct sunlight tends to always reveal shape and texture of irresponsive exhibits such as sculptures even though it is usually excluded due to its intensity. Apart from the lighting it provides, the windows also provide pleasant visual relief, thus reducing museum fatigue.

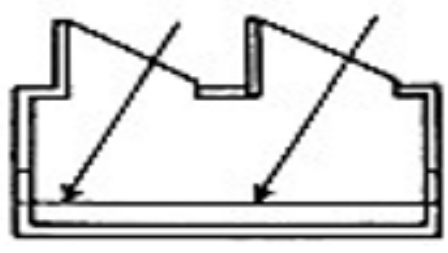

Monopitch rooflight

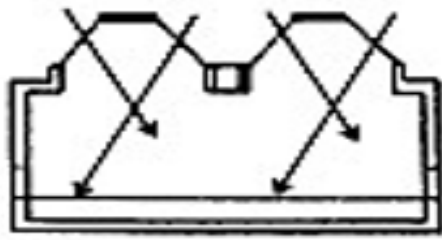

Inclined lantern lights

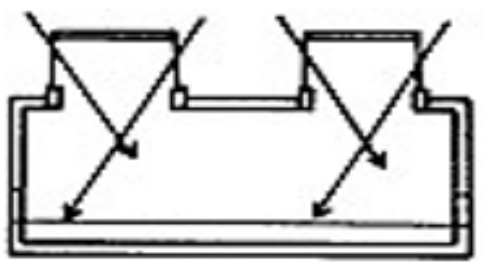

Lantern lights

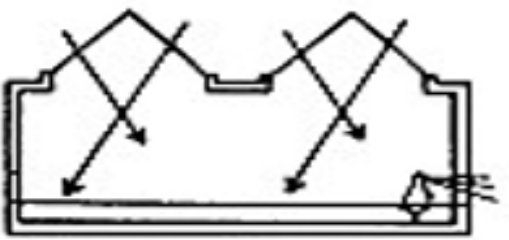

Ridge lights

Figure 1.0; long individual Roof light

Source: Ernst and Peter Neufert (2000)

Daylight penetrating through roof-lights will be diffused across the whole space to provide general background lighting or be directed towards the walls of a gallery to act as the main source of light for the exhibits there (Figure 1.0 and 2.0). Large areas of diffusing daylights are another solution to providing diffuse, general and exhibit lighting throughout a gallery space. For either situation, a successful day lighting design will depend on the architect and the lighting designer working closely together to devise the optimum form and structure of the roof-lights and their screening or redirecting surfaces. 


\subsubsection{Sunlight Restriction in gallery spaces}

It is important that direct sunlight has controlled entry into the gallery space to prevent overheating, glare and high iluminance. Exhibits that are insensitive to light or heat should be the ones under direct sunlight. The detailed design of north-facing windows and roof-lights are one possible solution to control direct sunlight. Fixed sunscreen devices can also be used, although consideration should be given to the transmission of these systems as they restrict daylight levels at times when sun screening is not required.

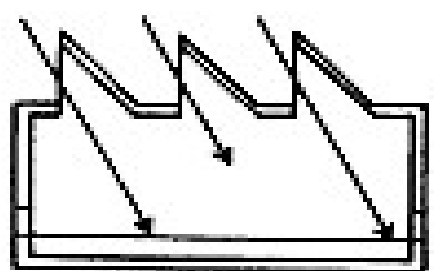

$900^{\circ}$ Inclined

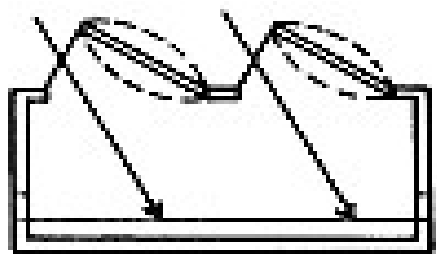

600 Inclination concave

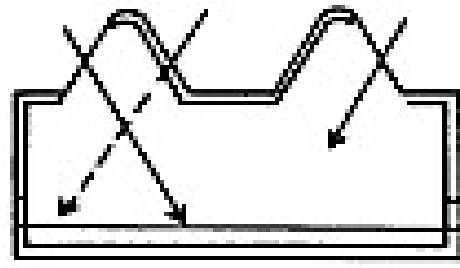

Opposed inclined surfaces

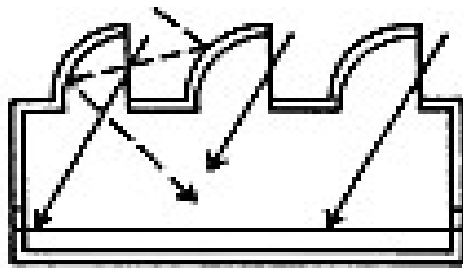

Rounded with white

External surfaces

Figure 2.0; Continuous Roof light

Source: Ernst and Peter Neufert (2000)

\subsubsection{Day lighting on Artworks}

The dynamic qualities of daylight have the ability to activate these spaces and redirect focus to the art. The incorporation of daylight in the gallery environment plays a vital role in a viewer's ability to fully comprehend the depth, shadow, tone and color in a work of art. It also reveals a dimension of time, as each passing cloud and the movement of the sun alters how art is viewed. Therefore, the use of daylight as a primary light source and design tool should not be ignored in museum and gallery design. According to Fördergemeinschaft Gutes Licht publications (FGL) (2007), for a long time, every new museum was built as a day light facility, despite the availability of artificial lighting. But that changed in the 1950s and 60s when it was realized how much damage daylight could do, especially to paintings and other organic materials. It was however stated that today, our knowledge of lighting engineering coupled with modern control and regulation technology makes it possible for daylight to be precisely directed and dosed.

Currently, a mixture of LED is the best kind of light for direct, as well as ambient lighting of an artwork. However, many modern and contemporary art galleries and museums are considering natural light as an important factor for ambient light. This is because according to several studies done by experts, the visual quality of viewing any artwork mainly depends on the field of view, which should have both aesthetic qualities and a certain degree of interest. Research conducted by Nick Baker and Koen Steemers (2002), opined that Artificial light is static and monotonous, which may lead to visual efficiency, but also results in 'emotional fatigue'. According to John H. Falk's study in Florida Museum of Natural History (1984), the viewing behavior of an adult is constant during the first 30 to 45 minutes of viewing, and after that they experience 'museum fatigue'. The use of natural light, which changes with time, can help in providing relief from this fatigue, Oliveria Steemers (2008)

\subsubsection{Conservation of Artworks}

According to Georginal Maddox (2019), the lighting of an artwork is an art in and of itself, one which takes into consideration many factors, from the temperature and colour of the light to its positioning and brightness

It is now a known fact that the light on an artwork should be about three times as bright or intense as the ambient light. However, as art pieces are sensitive to heat, infrared radiation (IR) and ultraviolet (UV) radiation, these should be avoided. Direct sunlight can reach over 30,000 lux (luminous flux per unit area), and hence, it is 
not recommended to use it in any circumstances on light sensitive artworks, because it leads to deterioration.

Studies have proven that the maximum desirable exposures for a painting are 30 foot-candles (ftc, a non-SI unit of iluminance or light intensity), which is equivalent to 325 lux. Light is one of the essential and influential elements in exhibition spaces. The role of light in art galleries and museums is not just to facilitate viewers to see the work, but also to preserve the artwork. Therefore, galleries are one of the most complex building types to be illuminated by daylight. Most galleries and museums prefer louvered top lighting system; skylight/roof-light as it is the best way to provide ambient light. Some use side-lighting, while others use reflective surfaces and directional natural light.

Therefore these values have recently been revised by the International Commission on Illumination (CIE) and is dependent on materials which are divided into three sensitivity classes. The most important are the maximum ililuminance and the allowed annual exposures to light. Ililuminance is a quantitative measurement of the intensity of a light source striking a surface, and is measured in lux the intensity of light on an artifact is calculated in both instantaneous illumination and annual illumination. Therefore, the maximum annual illumination is the total number of lux/hours an object can receive over the course of a year before long-term degradation will begin to occur as expressed in Table 1. This number is specific to an individual work of art and is determined by multiple factors including the type of media and applied pigmentation.

Table 1: Limiting ililuminances and annual exposures for material sensitivity classifications

\begin{tabular}{l}
\hline For items that are, very sensitive, such as \\
textiles, fur and feathers, dyed leather, prints, drawings, water col- 50 lux \\
ors, stamps, manuseripts, colored /Old photographs, miniatures, \\
transparencies, and unprimed thinly colored paintings on canvas. \\
\hline For items that are, moderately sensitive, such as \\
$\begin{array}{l}\text { Oil and tempera paintings, lacquerware, plastics, wood, furniture, } \\
\text { horn, bone, ivory, undyed leather and minerals }\end{array}$ \\
\hline For items that are, are less sensitive to light, such as \\
\hline Stone, eeramic, glass, and metal, but it is recommended \\
\end{tabular}

Source: CIE Div. 3 TC3-22

\subsubsection{Interior Finishes and Efficiency in gallery space}

Colour is considered one of the most principal spatial elements in the interior built environment. The colour of a space can subtly and even dramatically affect the lighting of an interior and this is so because the colors of an interior surface have the ability to absorb or reflect light. This scientific attribute of the surface colour is termed as Surface Reflectance K it either enhances or nullifies the distribution of light from the light source and this consequently has an effect on the efficiency of the luminaire distribution and consecutively the lighting efficiency of the space. Studies have proved that as much as one-third of the energy use of a lighting system depends upon the surrounding interior features, such as the ceiling height, windows, colour and reflectivity of room surfaces. Therefore, the interior colour scheme is considered in a unified whole, in the context of space design, artificial lighting and efficiency.

\section{Methodology}

\subsection{Study Area}

The study was carried out in Lagos State (Eti osa Local government). Lagos State

The coastal city of Lagos, currently the fifth largest city in the world, is situated within latitudes $6^{\circ} 23^{\prime} \mathrm{N}$ and $6^{\circ} 41^{\prime} \mathrm{N}$ and longitudes $2^{\circ} 42^{\prime} \mathrm{E}$ and $3^{\circ} 42 \mathrm{E}$ ). There is a 'current flurry of interest in Lagos' as the city comes under 'intense critical scrutiny', particularly from architectural and cultural theory and critical urban studies. Lagos has been the focus of few international art exhibitions (Gandy, 2005). The growing interest in Lagos is with good reasons. The mega-city is one of the most rapidly urbanizing areas in the world, and Nigeria's most populous conurbation. Its growth has been phenomenal, both demographically and spatially.

Eti-Osa is a Local government in Lagos State Nigeria with a population of 283,791 which represents $3.11 \%$ of the states' population. It lies on the narrow coastal lowland of the south eastern part of Lagos state and is 
situated on about 129.5 square kilometers of landmass along the foreshores of featuring sandy beaches, swamps, mangroves and creeks. It is bounded in the north by the Lagos lagoon, in the south by the Atlantic Ocean while at its western and eastern boundaries are Ojo and Ibeju-Lekki local government areas respectively. Within EtiOsa local Government are several important areas of Lagos State including Lagos Victoria Island, Lekki and Ikoyi. Before the Nigerian capital moved to Abuja, Eti-Osa local Government Area served alongside Lagos Island Local Government Area as the seat of the National Capital. Ikoyi, Victoria Island and Lekki are known to have some of the most opulent residential facilities in Nigeria and some most expensive real estate on the entire African continent. The Eti-Osa local government also shares borders with the Eko Atlantic which is a planned city on the Lagos Island of Lagos State and built on the land reclaimed from the Atlantic Ocean. The city adjoins Victoria Island district of Lagos city, and the Phase 1 area of Lekki to the north, while the entire Western, Eastern and southern borders is a coastline

\subsection{Research Design}

The method employed for this research was the objective and subjective approach which involves the use of technical measurement and field survey methods respectively. The objective approach involved the observation of the spaces, to take inventories, also the physical measurement were taken for ililuminance levels, window, wall and floor areas. The subjective approach on the other hand, involved the survey approach in which the gallery managements' perception on the optimisation of daylight in galleries was evaluated, by the use of structured questionnaire.

\subsection{Sample frame and technique}

The population of this study is Fifteen (15) art galleries which were purposively selected. The galleries are situated on the Lagos Island and Eti-Osa Local government area which constituted the sample frame. Total enumeration sampling technique was used to survey the responses of the staff that constitute the management team in each of the art gallery. Thus a total of 100 questionnaire were distributed based on the number of staff present in the galleries.

The selected galleries falls within the various gallery typology existent in the study area, and are divided into three (3) categories based on the type of structure used for galleries which are; Converted buildings, Spaces-in-Facilities and Purpose-Built Galleries.

Table 2: List of Art Galleries on the Lagos Island and Eti-Osa local government

\begin{tabular}{cll}
\hline & Art Gallery & LOCATION \\
\hline 1. & Abstract Strokes & Victoria Garden City, Lekki, Lagos State \\
2. & Art Exchange & Victoria Island, Lagos State. \\
3. & Art Twenty One & Eko Hotel \& Suites, Victoria Island, Lagos State \\
4. & Arthouse Contemporary & Foreshore Towers, Ikoyi, Lagos State \\
5. & Ltd & \\
6. & Kidi Museum & Victoria Island, Lagos State \\
7. & Lery & Freedom Park, off Broad Street, Lagos Island \\
8. & Mydrim Gallery Limited & \\
9. & Nike Art Gallery & Ikoyi, Lagos State \\
10. & Nimbus Art Gallery & Lekki Phase I, Lagos State, \\
11. & Omenka Gallery & Ikoyi, Lagos State \\
12. & Osh Gallery & Ikoyi, Lagos, State \\
13. & Quintessence Gallery & Victoria Island, Lagos State \\
14. & Red Door Art Gallery & Ikoyi, Lagos State \\
15. & Rele Art Gallery & Victoria Island, Lagos State \\
16. & Sach's Gallery & Onikan, Lagos State \\
17. & Signature Beyond & Lekki, Lagos State \\
18. & Terra Kulture & Victoria Island, Lagos, Nigeria \\
19. & The Hourglass Art Gallery & Victoria Island, Lagos Nigeria \\
20. & Thought Pyramid & Ikoyi, Lagos State \\
21. & Truview Art Gallery & Ikoyi, Lagos State \\
22. & Wangboye's Art Gallery & Shop F15, City Mall, Onikan \\
Sourd & Ikoyi, Lagos State
\end{tabular}


Table 3: Selected Galleries

\begin{tabular}{|c|c|c|}
\hline Name & Gallery Type & Location \\
\hline 1. Nike Art Gallery & Purpose-Built & Lekki Phase I, Lagos State, \\
\hline 2. Art Exchange & Space in facility & Victoria Island, Lagos State. \\
\hline 3. Didi Museum & Purpose-Built & Victoria Island, Lagos State \\
\hline 4. Nimbus Art Gallery & Converted & Ikoyi, Lagos State \\
\hline 5. Omenka Gallery & Purpose-Built & Ikoyi, Lagos, State \\
\hline 6. The Hourglass Art Gallery & Converted & Ikoyi, Lagos State \\
\hline 7. Terra Kulture & Purpose-Built & Victoria Island, Lagos State \\
\hline 8. $\overline{\text { Red Door Art }}$ & Converted & Victoria Island, Lagos State \\
\hline 9. Art Twenty One & Space in facility & $\begin{array}{l}\text { Eko Hotel \& Suites, Victoria } \\
\text { Island, Lagos State }\end{array}$ \\
\hline 10. Rele Art Gallery & Purpose-Built & Onikan, Lagos State \\
\hline 11. Mydrim Gallery Limited & Converted & Ikoyi, Lagos State \\
\hline 12. Thought Pyramid & Purpose-Built & Ikoyi, Lagos State \\
\hline 13. Quintessence Gallery & Space in facility & Ikoyi, Lagos State \\
\hline 14. Sach's Gallery & Converted & Lekki, Lagos State \\
\hline 15. Signature Beyond & Converted & Victoria Island, Lagos State \\
\hline
\end{tabular}

Source: Authors Compilation, 2018

\subsection{Method of data Analysis}

The data were processed from the questionnaires using Statistical Package for Social Scientists (SPSS) package. The results from the analysed data were summarized and presented.

\subsection{Findings.}

The reconnaissance survey revealed that each of the gallery has an average of 7 staff and the management consists of the following personnel: The Gallery director, Curator, Assistant curator, Gallery Manager, Gallery Assistant and Programs Officer. A total number of 100 questionnaire were administered based on the average number of staff present in visited galleries. Eighty One (81) responses making 78\% of the questionnaire were retrieved, all of them were valid for analysis. The table 4 below shows the mode of questionnaire administration The findings of this study reflect how the gallery management perceive use of daylight as an energy saving strategy in exhibition spaces. It highlights the roles and years of active work of the respondents in the gallery as it reflects on their perception about the study. It also reveals how the gallery design affects energy consumption and savings, Conservation considerations for the artworks were also assessed and comparisons were made with the International Commission on Illumination (CIE) standards. Patterns of various factors that provide the available illumination were also analyzed; the lux meter was used to measure the ililuminance in the exhibition spaces. The field survey was carried out on the galleries at middays in the month June, 2018.

Table 4: Administration of Questionnaire in the Galleries

\begin{tabular}{llll}
\hline Gallery & No & No Retrieved & $\%$ Returned \\
\hline 1. Nike gallery & Administered & & $100 \%$ \\
2. Art exchange & 11 & 11 & $66 \%$ \\
3. Didi museum & 6 & 4 & $60 \%$ \\
4. Nimbus gallery & 5 & 3 & $86 \%$ \\
5. Omenka art gallery & 7 & 6 & $80 \%$ \\
6. Hour glass art gallery & 5 & 4 & $86 \%$ \\
7. Terrakulture art gallery & 7 & 6 & $100 \%$ \\
8. Red door & 5 & 5 & $66 \%$ \\
9. Art 21 & 6 & 4 & $71 \%$ \\
10. Rele Art gallery & 7 & 5 & $86 \%$ \\
11. Mydrim art gallery & 7 & 6 & $86 \%$ \\
12. Thought pyramid & 7 & 6 & $86 \%$ \\
13. Quintessence & 7 & 6 & $86 \%$ \\
14. Sachs gallery & 7 & 6 & $57 \%$ \\
15. Signature beyond & 7 & 4 & $83 \%$ \\
\hline
\end{tabular}

Source: Authors Field Survey, 2018 
Table 5: Gender distribution

\begin{tabular}{lll}
\hline & Frequency & Percent (\%) \\
\hline MALE & 27 & 33.8 \\
FEMALE & 54 & 66.2 \\
Total & 81 & 100.0 \\
\hline
\end{tabular}

Source: Author's Field Survey, 2018

The gender distribution of gallery staff represented in table 5 shows that galleries have more female staff to male staff with the proportion of $66.2 \%$ and $33.8 \%$ respectively. This shows a good representation of the female gender in the art business.

Table 6: Years Spent in the Gallery

\begin{tabular}{lll}
\hline Years & Frequency & Percent (\%) \\
\hline less than 5 years & 51 & 62.5 \\
$5-10$ years & 10 & 12.5 \\
$10-15$ years & 20 & 25.0 \\
\hline Total & 81 & 100.0 \\
\hline
\end{tabular}

Source: Author's Field Survey, 2018

Twenty five percent $(25 \%)$ of the facility managers in the galleries have been staff for more than 10 years, while $12.5 \%$ have been working between 5 to 10 years as gallery staff. But in the last 5 years, $62.5 \%$ of the respondents became gallery staff, this further shows the potential of the evolving art business.

\subsection{Gallery types, sources and cost of power supply}

Galleries which are converted buildings have higher propensity to consume more energy. Table 7 shows that $43.8 \%$ of the galleries are converted buildings. They are found to depend largely on Petrol/Diesel Generators and Electricity from the Grid; $18.8 \%$ depend only on Petrol/Diesel Generators and $6.2 \%$ depend largely on solar systems and inverters.

Table 7: Type of Gallery Space and Type of Power Sources

$$
\text { Type Of Power Sources Used To Light }
$$

Exhibition Areas

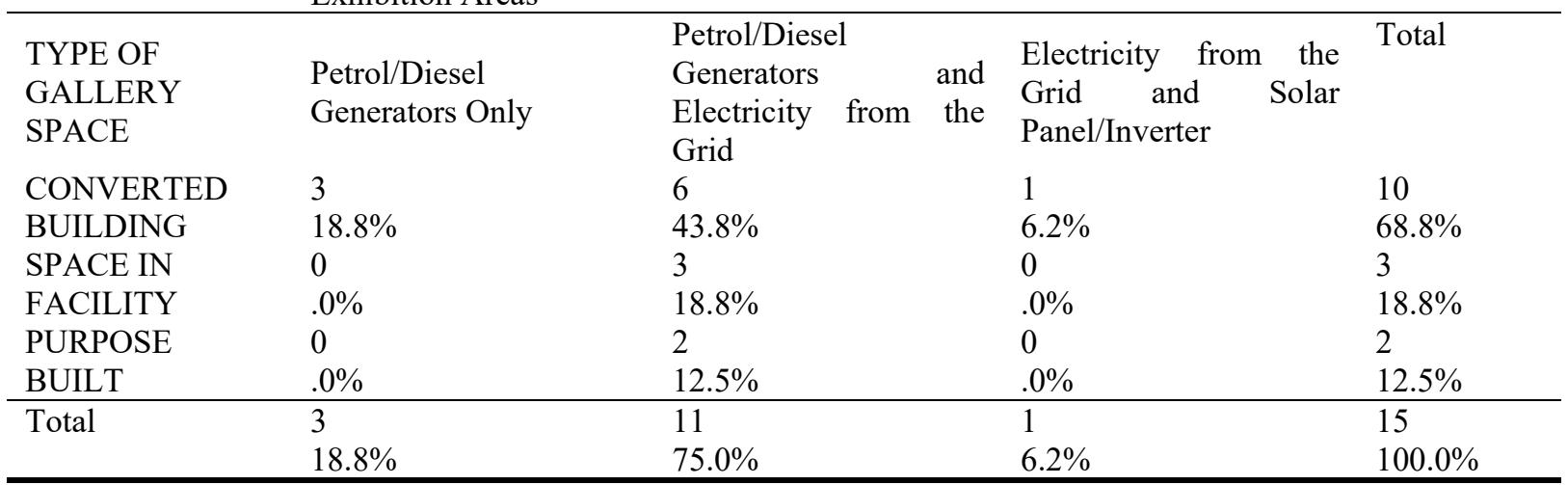

Source: Author's Field Survey, 2018

\subsection{Type of Gallery and Average Expenses on Petrol/Diesel Monthly}

Galleries that are converted buildings which constitute $68 \%$ of the proportion, spend the most on petrol and diesel this is between 50, 000 to 100, 000 Naira on a monthly basis (see Table 8), galleries which are Spaces-inFacilities which consist of $18.8 \%$ of the proportion also spend the equivalent of these amount on a monthly basis, while galleries that are Purpose-Built consist of $12.5 \%$ of the proportion. Purpose-Built galleries have the tendency to spend the least on petrol and diesel if the architecture is properly adapted to admit daylight, hence reducing total dependence on artificial lighting system 
Table 8: Type of Gallery and Average Expenses on Petrol/Diesel Monthly

\begin{tabular}{|c|c|c|c|c|}
\hline $\begin{array}{l}\text { TYPE OF } \\
\text { GALLERY }\end{array}$ & & $\begin{array}{l}50,000- \\
100,000\end{array}$ & $\begin{array}{l}\text { Over } \\
100,000\end{array}$ & TOTAL \\
\hline CONVERTED & Count & 3 & 7 & 10 \\
\hline \multirow[t]{2}{*}{ BUILDING } & $\begin{array}{l}\text { \% Within Average Expenses On Petrol/Diesel } \\
\text { Monthly }\end{array}$ & $75.0 \%$ & $66.7 \%$ & $68.8 \%$ \\
\hline & $\%$ Of Total & $18.8 \%$ & $50.0 \%$ & $68.8 \%$ \\
\hline SPACE IN & Count & 1 & 2 & 3 \\
\hline \multirow[t]{2}{*}{ FACILITY } & $\begin{array}{l}\text { \% Within Average Expenses On Petrol/Diesel } \\
\text { Monthly }\end{array}$ & $25.0 \%$ & $16.7 \%$ & $18.8 \%$ \\
\hline & $\%$ Of Total & $6.2 \%$ & $12.5 \%$ & $18.8 \%$ \\
\hline \multirow[t]{3}{*}{ PURPOSE BUILT } & Count & 0 & 2 & 2 \\
\hline & $\begin{array}{l}\text { \% Within Average Expenses On Petrol/Diesel } \\
\text { Monthly }\end{array}$ & $.0 \%$ & $16.7 \%$ & $12.5 \%$ \\
\hline & $\%$ Of Total & $.0 \%$ & $12.5 \%$ & $12.5 \%$ \\
\hline \multirow[t]{3}{*}{ TOTAL } & Count & 4 & 11 & 15 \\
\hline & $\begin{array}{l}\text { \% Within Average Expenses On Petrol/Diesel } \\
\text { Monthly }\end{array}$ & $100.0 \%$ & $100.0 \%$ & $100.0 \%$ \\
\hline & $\%$ Of Total & $25.0 \%$ & $75.0 \%$ & $100.0 \%$ \\
\hline
\end{tabular}

Source: Author's Field Survey,

3.3 Physical characteristics of galleries, types of lighting adopted and other factors that aid ililuminance; The physical observation of the galleries revealed that only $14.3 \%$ of the examined galleries had the North South orientation to maximize solar gain during the daytime, (see Table 9 ), 42.9\% had windows with sill height below $0.9 \mathrm{~m}, 14.3 \%$ adopted to use of clerestory windows to maximize the available wall area to display art works while also admitting daylight, $71.4 \%$ of the galleries had no protection whatsoever over their windows $28.6 \%$ utilized the ultraviolent treatment on their glazed windows and overhangs as shading devices. All examined galleries had brightly colored ceiling and interior wall finishes to aid the overall ambience of the exhibition areas.28.6\% of the galleries had floor finishes that were not brightly colored.

Table 9: Physical Characteristics of Galleries

\begin{tabular}{llll}
\hline Design Feature & Frequency & Percent & Cumulative Percent \\
Building Form & & 57.1 & 57.1 \\
Linear & 4 & 42.9 & 42.9 \\
Broad With Deep Interior Spaces & 3 & 100.0 & 100.0 \\
Total & 7 & & \\
\hline Building Orientation & 1 & 14.3 & 14.3 \\
North-South & 4 & 57.1 & 71.4 \\
NorthEast-SouthWest & 2 & 28.6 & 100.0 \\
NorthWest-SouthEast & & & \\
Type of Lighting & 3 & 42.9 & 42.9 \\
Combination of Daylight and Artificial & 4 & 57.1 & 100.0 \\
Artificial Light Only & 7 & 100.0 & \\
Total & & & \\
\hline Fenestration Type & 3 & 42.9 & 42.9 \\
Curtain Wall & 1 & 14.3 & 57.1 \\
None & 1 & 14.3 & 71.4 \\
Casement Window & 1 & 14.3 & 85.7 \\
Projected Window & 1 & 14.3 & 100.0 \\
Clerestory windows & 7 & 100.0 & \\
Total & & & \\
\hline Window Location & 2 & 28.6 & 28.6 \\
0.9m & 1 & 14.3 & 42.9 \\
High Level Window & 3 & 42.9 & 85.7 \\
Below 0.9m & 1 & 14.3 & 100.0 \\
No Window & 7 & 100.0 & \\
Total & 1 & 14.3 & 16.7 \\
\hline Window Size ( Area ) & & & \\
75\% and above of wall area & & & \\
\hline
\end{tabular}




\begin{tabular}{llll}
\hline Between $60-74 \%$ of the wall area & 1 & 14.3 & 16.7 \\
Less than 20\% of the wall area & 4 & 57.1 & 66.7 \\
Total & 6 & 85.7 & 100.0 \\
\hline Window Protection & 1 & & \\
Fully Protected by Overhang & 1 & 14.3 & 14.3 \\
UV Treated Glazing & 5 & 14.3 & 28.6 \\
Not Protected at all & 7 & 71.4 & 100 \\
Total & & 100.0 & \\
\hline Interior Finishes & 7 & & \\
Color of Wall Finish & & 100.0 & 100.0 \\
Bright & 5 & & \\
Floor Finish & 1 & 71.4 & 71.4 \\
Floor Tiles & 1 & 14.3 & 85.7 \\
Cement Sand Screed & & 14.3 & 100.0 \\
Parquet Floor & & \\
Color of Ceiling finishes & 7 & 100.0 & \\
Bright Colored finishes & &
\end{tabular}

Source: Author's Computation from Field Observations, 2018

\subsection{Ililuminance levels in Exhibition areas}

According to (Table 10) $66.7 \%$ of the galleries were able to achieve recommended lux values with the combination of both artificial and daylight while $33.3 \%$ of the galleries were not able to properly combine both light sources to achieve the recommended 50 lux for this category of art works, this is largely because the amount of daylight allowed into the spaces were not properly controlled with appropriate shading devices. All galleries that used the artificial light source exceeded the recommended lux values in this category, this is because emphasis is usually placed mainly on the display of art works much more than its conservation. Galleries that made provision for daylight were assessed and the relationships between the window location and sizes were computed with respect to the measured and recommended lux values.

Table 10: Illumination for Category 1 Art Works

\begin{tabular}{|c|c|c|c|c|}
\hline \multicolumn{2}{|l|}{$\begin{array}{l}\text { Types of } \\
\text { Illumination }\end{array}$} & $\begin{array}{l}\text { AVERAGE } \\
\text { VALUE } \\
\text { 20-50lux }\end{array}$ & $\begin{array}{l}\text { TOTAL LUX } \\
\text { above } 50 \text { lux }\end{array}$ & Total \\
\hline Combination of Daylight & Count & 2 & 1 & 3 \\
\hline & $\%$ Within types of illumination & $66.7 \%$ & $33.3 \%$ & $100.0 \%$ \\
\hline Artificial & $\%$ Within average total lux value & $100.0 \%$ & $20.0 \%$ & $42.9 \%$ \\
\hline Artificial & Count & 0 & 4 & 4 \\
\hline \multirow[t]{2}{*}{ Light Only } & $\%$ Within types of illumination & $.0 \%$ & $100.0 \%$ & $100.0 \%$ \\
\hline & $\%$ Within average total lux value & $.0 \%$ & $80.0 \%$ & $57.1 \%$ \\
\hline \multirow[t]{3}{*}{ Total } & Count & 2 & 5 & \\
\hline & $\%$ Within types of illumination & $28.6 \%$ & $71.4 \%$ & $100.0 \%$ \\
\hline & $\%$ Within average total lux value & $100.0 \%$ & $100.0 \%$ & $100.0 \%$ \\
\hline
\end{tabular}

Source: Author's Computation from Field Observations, 2018

\subsection{Window Sizes and Average Lux Values from Daylight}

Chand (1996) recommended that window/wall area for natural ventilation and lighting in an internal space for warm and humid climate respectively to be between $30-50 \%$ of the exposed wall area. $66.6 \%$ of the galleries that admit daylight meet this criteria, however half of this percentage which amounts to $33.3 \%$ of the galleries exceed the maximum required lux value for this category of artworks (see Table 11). This implies that sufficient window openings were provided based on Chand's recommendations but were not necessarily suitable for the artworks. Windows that are less than $20 \%$ of exposed wall area are within the recommended limits and provide required ililuminance for this category of art work. 
Table 11: Window sizes and Day lighting for Category 1 Art Works

\begin{tabular}{|c|c|c|c|c|c|c|}
\hline \multirow[b]{2}{*}{ Window Size } & & \multicolumn{2}{|c|}{$\begin{array}{l}\text { AVERAGE } \\
\text { DAYLIGHT }\end{array}$} & \multicolumn{2}{|r|}{ FOR } & \multirow[t]{2}{*}{ Total } \\
\hline & & 0-10lux & 20-50lux & $\begin{array}{l}\text { above } \\
\text { lux }\end{array}$ & 50 & \\
\hline \multirow[t]{2}{*}{$75 \%$ and above of wall area } & Count & 0 & 0 & 1 & & 1 \\
\hline & $\begin{array}{l}\% \text { Within average lux for } \\
\text { daylight }\end{array}$ & $.0 \%$ & $.0 \%$ & $100.0 \%$ & & $33.3 \%$ \\
\hline \multirow{2}{*}{$\begin{array}{l}\text { Between } 50-74 \% \text { of the wall } \\
\text { area }\end{array}$} & Count & 1 & 0 & 0 & & 1 \\
\hline & $\begin{array}{l}\text { \% Within average lux for } \\
\text { daylight }\end{array}$ & $100.0 \%$ & $.0 \%$ & $.0 \%$ & & $33.3 \%$ \\
\hline \multirow{2}{*}{$\begin{array}{l}\text { Less than } 20 \% \text { of the wall } \\
\text { area }\end{array}$} & Count & 0 & 1 & 0 & & 1 \\
\hline & $\begin{array}{l}\text { \% Within average lux for } \\
\text { daylight }\end{array}$ & $.0 \%$ & $100.0 \%$ & $.0 \%$ & & $33.3 \%$ \\
\hline \multirow[t]{3}{*}{ Total } & Count & 1 & 1 & 1 & & 3 \\
\hline & $\%$ Within window size & $33.3 \%$ & $33.3 \%$ & $33.3 \%$ & & $100.0 \%$ \\
\hline & $\begin{array}{l}\% \text { Within average } \\
\text { lux for daylight }\end{array}$ & $100.0 \%$ & $100.0 \%$ & $100.0 \%$ & & $100.0 \%$ \\
\hline
\end{tabular}

Source: Estimated from Author's Field Survey, 2018

\subsection{Types of Illumination and Average Total Lux Values}

Table shows the illumination types available as at the period of assessing the gallery spaces for the category 2 type of art works, $28.6 \%$ of the galleries make use of a combination of both day and artificial lighting for energy savings and most importantly to enhance the ambient lighting. However these galleries exceed the recommended lux values for the artworks which is 200lux. $42.9 \%$ of the galleries made use of just day lighting at the time of visit and $33.3 \%$ of these galleries exceed the required ililuminance. The use of daylight in the gallery spaces was found to be of benefit in energy savings, however if proper shading devices were installed, the ililuminance level of the exhibition areas would further reduce the light intensity in the spaces.

Illumination for Category 2 Art Works

Windows Size and Average Lux Value for Daylight

\begin{tabular}{|c|c|c|c|c|c|}
\hline \multirow[b]{2}{*}{ Types of Illumination } & & \multicolumn{3}{|c|}{ Average Total Lux Value } & \multirow[t]{3}{*}{ Total } \\
\hline & & & $150-$ & above & \\
\hline \multirow{4}{*}{$\begin{array}{l}\text { Combination of Daylight } \\
\text { and } \\
\text { Artificial }\end{array}$} & & 0 & 0 & $?$ & \\
\hline & Count & 0 & 0 & 2 & 2 \\
\hline & $\begin{array}{l}\text { \% within types of } \\
\text { Illumination }\end{array}$ & $.0 \%$ & $.0 \%$ & $100.0 \%$ & $100.0 \%$ \\
\hline & $\begin{array}{l}\% \text { within average total lux } \\
\text { value }\end{array}$ & $.0 \%$ & $.0 \%$ & $66.7 \%$ & $28.6 \%$ \\
\hline \multirow[t]{3}{*}{ Daylight Only } & Count & 2 & 0 & 1 & 3 \\
\hline & $\begin{array}{l}\% \text { within types of } \\
\text { illumination }\end{array}$ & $66.7 \%$ & $.0 \%$ & $33.3 \%$ & $100.0 \%$ \\
\hline & $\begin{array}{l}\% \text { within average total lux } \\
\text { value }\end{array}$ & $66.7 \%$ & $.0 \%$ & $33.3 \%$ & $42.9 \%$ \\
\hline \multirow[t]{3}{*}{ Artificial Light Only } & Count & 1 & 1 & 0 & 2 \\
\hline & $\begin{array}{l}\% \text { within types of } \\
\text { illumination }\end{array}$ & $50.0 \%$ & $50.0 \%$ & $.0 \%$ & $100.0 \%$ \\
\hline & $\begin{array}{l}\% \text { within average total lux } \\
\text { value }\end{array}$ & $33.3 \%$ & $100.0 \%$ & $.0 \%$ & $28.6 \%$ \\
\hline \multirow[t]{3}{*}{ Total } & Count & 3 & 1 & 3 & 7 \\
\hline & $\begin{array}{l}\% \text { within types of } \\
\text { illumination }\end{array}$ & $42.9 \%$ & $14.3 \%$ & $42.9 \%$ & $100.0 \%$ \\
\hline & $\begin{array}{l}\% \text { within average total lux } \\
\text { value }\end{array}$ & $100.0 \%$ & $100.0 \%$ & $100.0 \%$ & $100.0 \%$ \\
\hline
\end{tabular}

Source: Author's Field Survey, 2018

$80 \%$ of the galleries that admit daylight meet Chands recommendation for day lighting, however $33 \%$ of these galleries exceed the maximum required lux value for this category of artworks. This implies that this category of art works could allow for sufficient amount of daylight; due to the sensitivity of the artworks.20\% 
of the gallery spaces have windows that are less than $20 \%$ of exposed wall area.

Window sizes and Day lighting for Category 2 Art Works

\begin{tabular}{|c|c|c|c|c|c|}
\hline \multirow[t]{2}{*}{ Window Size } & & \multicolumn{3}{|c|}{ AVERAGE LUX FOR DAYLIGHT } & \multirow[t]{2}{*}{ Total } \\
\hline & & $0-50 \operatorname{lux}$ & 150-200lux & above 200lux & \\
\hline \multirow{3}{*}{$\begin{array}{l}75 \% \text { and above of } \\
\text { wall area }\end{array}$} & Count & 1 & 1 & 1 & 3 \\
\hline & $\%$ within Window Size & $33.3 \%$ & $33.3 \%$ & $33.3 \%$ & $100.0 \%$ \\
\hline & $\begin{array}{l}\% \text { within average lux for } \\
\text { daylight }\end{array}$ & $33.3 \%$ & $100.0 \%$ & $100.0 \%$ & $60.0 \%$ \\
\hline \multirow{3}{*}{$\begin{array}{l}\text { Between } 40-59 \% \text { of } \\
\text { the wall area }\end{array}$} & Count & 1 & 0 & 0 & 1 \\
\hline & $\%$ within Window Size & $100.0 \%$ & $.0 \%$ & $.0 \%$ & $100.0 \%$ \\
\hline & $\begin{array}{l}\% \text { within average lux for } \\
\text { daylight }\end{array}$ & $33.3 \%$ & $.0 \%$ & $.0 \%$ & $20.0 \%$ \\
\hline \multirow{3}{*}{$\begin{array}{l}\text { Less than } 20 \% \text { of the } \\
\text { wall area }\end{array}$} & Count & 1 & 0 & 0 & 1 \\
\hline & $\%$ within Window Size & $100.0 \%$ & $.0 \%$ & $.0 \%$ & $100.0 \%$ \\
\hline & $\begin{array}{l}\% \text { within average lux for } \\
\text { daylight }\end{array}$ & $33.3 \%$ & $.0 \%$ & $.0 \%$ & $20.0 \%$ \\
\hline \multirow[t]{3}{*}{ Total } & Count & 3 & 1 & 1 & 5 \\
\hline & $\%$ within & $60.0 \%$ & $20.0 \%$ & $20.0 \%$ & $100.0 \%$ \\
\hline & $\begin{array}{l}\text { Window Size } \\
\% \text { within } \\
\text { average lux for daylight }\end{array}$ & $100.0 \%$ & $100.0 \%$ & $100.0 \%$ & $100.0 \%$ \\
\hline
\end{tabular}

Source: Author's Field Survey, 2018

\subsection{Perception on optimization of daylight and use of artificial lighting;}

Controlled use of daylight was preferred by $43.8 \%$ of the respondents as a cost effective means of lighting the exhibition areas, the use of Solar panels with the proportion of $37.5 \%$ was another preferred alternative due to cost efficiency. Electricity from the grid had the least preference with the proportion of $18.8 \%$ and this is largely due to the inconsistency of power supply and overestimated billing systems if available (see Table 12).

Table 12: Lighting Sources in the gallery

\begin{tabular}{lllll}
\hline Source & Frequency & Percent & $\begin{array}{l}\text { Valid } \\
\text { Percent }\end{array}$ & Cumulative Percent \\
\hline Solar Panel/Inverter & $31 \%$ & $37.5 \%$ & $37.5 \%$ & $37.5 \%$ \\
Controlled Use Of Daylight & $35 \%$ & $43.8 \%$ & $43.8 \%$ & $81.2 \%$ \\
Electricity from the Grid & $15 \%$ & $18.8 \%$ & $18.8 \%$ & $100.0 \%$ \\
Total & $81 \%$ & $100.0 \%$ & $100.0 \%$ & \\
\hline
\end{tabular}

Source: Author's Field Survey, 2018

\subsection{Staff Perception of Daylight and Effects of Artificial Light}

Respondents agreed to the use of controlled Daylight for its energy and cost saving benefits by the proportions of $37.5 \%$ and $31.2 \%$ respectively (see Table 13 ). It also revealed that daylight is perceived by the gallery staff as effective in enhancing the spatial quality by the proportions of $31.2 \%$ and $37.5 \%$ respectively. $43.8 \%$ of the respondents neither agree nor disagree to the fact that daylight enhances experience of viewing artworks, however $7.4 \%$ and $43.8 \%$ agree and strongly agree respectively to this fact. $43.8 \%$ of the respondents seem unsure as to the damaging effects of intensive and uncontrolled artificial lighting while $12.5 \%$ and $25 \%$ agree and strongly agree to it, however $18.8 \%$ disagree that artificial lights have a damaging effect on the art works. $31.2 \%$ of the respondents strongly agree that color distortions occur with the use of some artificial lights. The strategic use of daylight is considered a welcome idea however, $31.2 \%$ feel unsure about this concept. 
Table 13: Staff Perception of Daylight and Effects of Artificial Light

\begin{tabular}{llllll}
\hline Staff Perception on & $\begin{array}{l}\text { Strongly } \\
\text { Agree }\end{array}$ & Agree & $\begin{array}{l}\text { Neither } \\
\text { agree/ } \\
\text { Disagree }\end{array}$ & Disagree & $\begin{array}{l}\text { Strongly } \\
\text { Disagree }\end{array}$ \\
\hline $\begin{array}{l}\text { Controlled Use Of Daylight Will Provide } \\
\text { Adequate And Better Illumination at a Reduced }\end{array}$ & $31.2 \%$ & $37.5 \%$ & $6.2 \%$ & $25.0 \%$ & 0.0 \\
Cost And Energy Consumption & & & & \\
$\begin{array}{l}\text { Controlled Use Of Daylight Further } \\
\text { Enhances The Spatial Quality Of Exhibition }\end{array}$ & $31.2 \%$ & $37.5 \%$ & $31.2 \%$ & 0.0 & 0.0 \\
$\begin{array}{l}\text { Areas } \\
\text { Daylight Improves Viewing Experience }\end{array}$ & $7.4 \%$ & $43.8 \%$ & $43.8 \%$ & $6.2 \%$ & 0.0 \\
$\begin{array}{l}\text { Intensive And Uncontrolled Artificial Lighting } \\
\text { Damages Artworks }\end{array}$ & $12.5 \%$ & $25 \%$ & $43.8 \%$ & $18.8 \%$ & 0.0 \\
$\begin{array}{l}\text { Some Artificial Lighting Distort Actual Color Of } \\
\text { Artworks }\end{array}$ & $31.2 \%$ & $43.8 \%$ & $12.5 \%$ & $12.5 \%$ & 0.0 \\
$\begin{array}{l}\text { Adoption Of Daylight Strategies is a welcome } \\
\text { Idea }\end{array}$ & $18.8 \%$ & $50 \%$ & 3 & & 0.0 \\
\end{tabular}

Source: Author's Field Survey, 2018

\subsection{Power Usage in the Gallery Space}

Table 14 shows the respondents perceived areas of significance for power usage in the gallery space. Power is mostly used for thermal comfort, visual comfort, Lighting the art works and Security. The result shows that the highest Power Usage Index (PUI) is 5.4198 which is the perceived power usage for lighting the art works while the lowest PUI is 4.2592 which is the perceived power usage for thermal comfort. Lighting for the art works is prioritized above all other areas where power is needed in the art gallery space.

Table 14: Table Power Usage in the Gallery Space

\begin{tabular}{|c|c|c|c|c|c|c|c|c|c|c|c|}
\hline \multirow{2}{*}{$\begin{array}{l}\text { Ranking } \\
\text { Elements }\end{array}$} & \multicolumn{8}{|c|}{ Importance Index } & \multirow[b]{2}{*}{$\mathrm{X}$} & \multirow[b]{2}{*}{$\mathrm{D}$} & \multirow[b]{2}{*}{ RANK } \\
\hline & 5 & 4 & 3 & 2 & 1 & $N R(f)$ & SWV & $\begin{array}{l}\text { SWV } \\
\text { /NR(f) }\end{array}$ & & & \\
\hline Thermal Comfort & 225 & 120 & 0 & 12 & 0 & 81 & 345 & 4.2592 & 4.7284 & -0.4692 & 4 \\
\hline Visual Comfort & 225 & 148 & 0 & 0 & 0 & 81 & 345 & 4.6049 & & -0.1235 & 3 \\
\hline Lighting Art & 375 & 64 & 0 & 0 & 0 & 81 & 439 & 5.4198 & & 0.6914 & 1 \\
\hline Security & 255 & 12 & 0 & 0 & 0 & 81 & 375 & 4.6296 & & -0.0988 & 2 \\
\hline
\end{tabular}

Source: Author's Field Survey, 2018

Keys: 5 - Very Important 4- Important 3- Not Sure 2- Not Important 1-Not Important At All

NR $(f)=$ Number of Respondents or Summary of Frequency:

SWV = Satisfaction Weight Value

PUI = Power Usage Index (SWV/NR); $\quad \mathrm{X}=$ Average

Mean $\left(\sum \mathrm{PFS} / \mathrm{N}\right) \quad \mathrm{D}=$ Deviation $(\mathrm{PFS}-\mathrm{X})$

4. Deduction from Research Findings

\section{A. Socio-Economic Characteristics of Respondents}

i. $\quad 62.5 \%$ of respondents became gallery staff in the last 5 years

ii. The highest proportion of gallery staff are females at $66.2 \%$

\section{B. Gallery Type and Power Sources}

i. The highest proportions of $68.9 \%$ of the galleries are converted spaces

ii. The highest proportions of $43.8 \%$ of these galleries that are converted spaces depend largely on generators and the poor electricity from the grid. They spend over 100, 000 monthly on diesel and petrol.

\section{Cost Effective and Energy Efficient Means Of Lighting Exhibition Areas}

i. The highest proportions $68.7 \%$ of the respondents agree to the use of daylight as cost effective and energy 
efficient

ii. $\quad 37.5 \%$ of the respondents prefer the use of Solar Panel/Inverter as an energy efficient alternative

iii. $\quad 43.8 \%$ are uncertain as to the effects of intense and uncontrolled artificial lighting

iv. The highest proportions of $68.8 \%$ are of the opinion that adoption of daylight strategies for energy efficiency is a welcome idea.

\section{Physical Characteristics and Ililuminance Values}

i. The least proportions $14.3 \%$ utilized the North South orientation to maximize solar gain during the daytime.

ii. The least proportions of $14.3 \%$ adopted to use of clerestory windows to maximize the available wall area

iii. The highest proportions of $71.4 \%$ of the galleries had no protection whatsoever over their windows

iv. $28.6 \%$ utilized the ultraviolent treatment on their glazed windows and overhangs as shading devices.

v. All examined galleries had brightly colored ceiling and interior wall finishes

vi. $\quad 66.7 \%$ of the galleries achieved recommended lux values with day and artificial light

vii. All artificially lit galleries exceed the recommended lux values

viii. $\quad 33.3 \%$ of the galleries with $75 \%$ of window to wall area exceed the lux limits

ix. Brightly colored interior finish contribute to the ililuminance of the gallery interior spaces

\section{Conclusion and Recommendations}

The analysis reflects how gallery managements perceive use of day lighting strategies in exhibition spaces which consequently reflects on the design considerations adopted in the examined galleries. Lighting for the art works has been found to be prioritized above all other areas where power is needed in the art gallery space. A higher proportion of the managements team admit to the fact that day lighting strategies are energy efficient and cost effective but have not practically adopted them because it is often difficult and expensive to achieve optimal day lighting with converted buildings, especially in expensive areas where these galleries are mostly located. Rightly placed fenestrations and brightly colored interior finishes have been found to enhance the overall ililuminance of the exhibition areas. The fenestrations must be properly shaded and strategically located to ensure that the recommended ililuminance limits are reached and that wall areas are maximized for the display of these art works.

This study also reveals the lighting strategies presently adopted in the existing galleries and hopes to redefine the design considerations employed in order to match the current trend of sustainability and energy efficiency measures. It further revealed the perception of gallery stakeholders on the introduction of day lighting strategies.The study stands to aid policy makers on informed energy legislations, it also informs gallery owners, enthusiasts, stakeholders, consultant, and facility managers on potential benefits of adopting day lighting strategies.

\section{Acknowledgement}

The researchers acknowledged the support of the research assistant in the administration of the questionnaires and the support of every respondents who participated through their responses.

\section{References}

Adeleke, K. (2010): Green Building Code. A priority for Sustainable Development. Paper presented of the Architects Colloquium organized, by The Nigeria Institute of Architects in Abuja, March 2010.

Ameer, M. (2015) "Importance of Daylight in Art Galleries" Sustainable Environmental Design Research Paper for the Architectural Association School of Architecture Graduate School.

Arvind, D. and Tejinder, S. (2009). Energy Conservation with Energy Efficient Lighting. WSEAS Transactions on Environment and Development, 5,630-639

BussinessDay (2017) Leaping forward: A look at Nigeria's art space in 2017. Retrieved from https://businessday.ng/arts-bdlife-arts/article/leaping-forwardlook-nigerias-art-space- 2017/ (accessedJune, 2019)

Ernst and Peter Neufert (2000), Neufert Architects' data, 3rd edition, Blackwell science LTD.

Fernanda Oliveira, and Koen, Stemmers (2008) Daylight and Museums - A survey on the Behavior and Satisfaction of Visitors "in Passive and Low Energy Architecture, Proceedings of PLEA "08, Dublin

Fördergemeinschaft Gutes Licht Publications (2007). Good Lighting for Museums, Galleries and Exhibitions. Issue 18

Gandy, M. (2005). Learning From Lagos, New Left Rev. 33: 36-52. "An Urbanizing World: Global Report on Human Settlements. Oxford: Oxford University Press.

Georgina Maddox (2019).Here comes the sun: the importance of daylight in galleries and museums, www.stirworld.com (accessed $4^{\text {th }}$ March 2021).

Joshua, O., and John. O. (2015). Visual Arts Practice: A Catalyst for Developing a Local Economy in Nigeria. 
Arts and Design Studies 36, 35-38

Liliana, O., Umesh, A., Chayapa, C., and Beltina, M. (2004). Evaluating the Daylight Performance of Three Museum Galleries. ASES National Solar Energy Conference, Portland, 2004.

Nick Baker and Koen Steemers, (2002) 'Daylight Design of Buildings' James and James (science publisher London, UK)

Onal K., (2017) .Literature Study on Art Gallery .Retrieved from https://www.slideshare.net/onalkothari/literature-study-on-art-gallery, retrieved February, 2020

Robertson, I. (2008) .The art business in London Routledge. https:/www.routledge.com/The-ArtBusiness/Robertson-Robertson/p/book/9780415391580 (accessed $4^{\text {th }}$ March 2021).

Sergio, A. (2008). Daylight for Energy Savings and Psycho-Physiological WellBeing in Sustainable Built Environments. Journal for sustainable development.

Ajayi Oluwole Oluwaseun (B.Tech, M.tech, Ph.D, Mnia) Studied Architecture to M.tech level at the Ladoke Akintola University of Technology, Ogbomoso. He bagged his Ph.D at the University of Johannesburg, South Africa.

$\mathrm{He}$ is a member of the Nigeria Institute of Architects, South Arica Council of Architecture Professionals and currently lectures in the Department of Architecture, Lautech, Ogbomoso. His research focus is centered on Housing, Construction health\& Safety and Construction Economics.

Akande Oluwaseun Mayowa (B.Tech, M.tech ) Studied Architecture to M.tech level at the Ladoke Akintola University of Technology, Ogbomoso. His research focus is on Housing, Bioclimatic Architecture and Architectural Designs.

Onigbogi Olayinka Odunola (B.Tech, M.tech ) Studied Architecture to M.tech level at the Ladoke Akintola University of Technology, Ogbomoso. She is currently lecturing and also on her Ph.D studies at the same University. Her research focus is on Housing, Urban design and Sustainable Architecture. 